Tarih Kültür ve Sanat Araştırmaları Dergisi

Revue des Recherches en Histoire Culture et Art

مجلة البحوث التاريخية و الثقافية و الفنية
Vol. 7, No. 2, June 2018

Copyright (C) Karabuk University

http://kutaksam.karabuk.edu.tr

\title{
DOI: 10.7596/taksad.v7i2.1596
}

Citation: Tolstolutskaya, E., Mikhailova, E., Sleptsova, S., Svischev, G., \& Kuzmina, O. (2018). Metaphoric Expression of Allusion in the Headlines of French Political Articles. Journal of History Culture and Art Research, 7(2), 132-138. doi:http://dx.doi.org/10.7596/taksad.v7i2.1596

\section{Metaphoric Expression of Allusion in the Headlines of French Political Articles}

Evguenya V. Tolstolutskaya ${ }^{1}$, Elena N. Mikhailova², Svetlana V. Sleptsova ${ }^{3}$, Guennady V. Svischev ${ }^{4}$, Oksana V. Kuzmina $^{5}$

\begin{abstract}
The article analyzes metaphorical constructions expressing the hint. The study is carried out on the basis of the political article headlines of contemporary prestigious French editions of "Monde diplomatique", "Le Figaro", "Télérama". The hint is regarded as an indirect speech act reflecting the meaning of information implicitly. The classification of article headlines is based on the metaphors types: "Anthropomorphic metaphor", "Metaphor of nature", "Social metaphor", "Artifact metaphor" and "Metaphor of irreality". Each type of metaphor is considered in connection with the conceptual spheres related to it. The study showed that in the language of modern French press there is a great number of headline structures containing: "Anthropomorphic metaphor" with such conceptual spheres as "Anatomy and physiology", "Disease", "Family"; "Metaphor of nature" with such concepts as "Animal world", "Plant world"; "Social metaphor", the sources of this metaphorical expansion are such conceptual spheres as "Crime", "War", "Theater", "Game and sport"; "Artifact metaphor" with the concepts "House" and "Mechanism".
\end{abstract}

Keywords: Hint, Metaphor, Newspaper discourse, Indirect speech act, Concept, Metaphorical expansion.

\footnotetext{
${ }^{1}$ Belgorod State University Russia, 308015, Belgorod, Pobeda Street, 85. E-mail: tolstolutskaya_e@bsu.edu.ru

2 Belgorod State University Russia, 308015, Belgorod, Pobeda Street, 85.

${ }^{3}$ Belgorod State University Russia, 308015, Belgorod, Pobeda Street, 85.

${ }^{4}$ Belgorod State University Russia, 308015, Belgorod, Pobeda Street, 85.

${ }^{5}$ Belgorod State University Russia, 308015, Belgorod, Pobeda Street, 85.
} 


\section{Introduction}

The modern linguistic paradigm has obtained the name "anthropocentric" due to the fact that a man has become the most important aspect for consideration of various linguistic phenomena, a kind of "measure" of everything connected with a language. It is not by accident that in recent years within the framework of the new linguistic ontology more and more attention has been paid to the problems associated with the study of discourse considering the variety of all its manifestations, since it embodies what can be designated as "human space" most fully.

\section{Methods}

A complex analysis technique that combines the techniques of structural semantics, cognitive linguistics and discourse analysis was used in the study. Empirical data were obtained by partial selection of illustrative examples from such prestigious French editions as "Monde diplomatique", "Le Figaro", "Télérama". In the course of the analysis the field method, as well as the techniques of component and distributive analysis were used, which made it possible to identify the connections between the direct and idiomatic meanings of the metaphorical units under study that are used to express the hint in the headlines of French political articles.

\section{Discussion}

Peculiarities of modern society development have led to the situation when the publicistic discourse has acquired a significant place in modern discursive studies. This is due, firstly, to the fact that this type of discourse is one of the most dynamically developing spheres of modern mass communication. Secondly, the publicistic discourse is distinguished by a special kind of creativity of its representatives who constantly look for the new forms of influence on an addressee and update the old ones. Thirdly, in this type of discourse all sorts of trends in language development are manifested clearly regardless of the typological affiliation of the language. Finally, this type of discourse, unlike any other one, combines the traits of different types of discourse. It is not accident that recent studies have revealed such its trait as heterogeneity. M. López Díaz writes about it in particular emphasizing that the peculiarity of the publicistic discourse is provided by a special kind of intertextuality and interdiscursivity. At the same time the distinctive feature of the publicistic discourse is that it focuses on its inherent persuasive strategies (López Díaz, 2006).

In modern linguistics the publicistic discourse is considered as a special kind of distant form of communicative activity of institutional and cognitive nature. This characteristic of the publicistic discourse is due to the fact that its main participants are representatives of written media, on the one hand, and mass audience, on the other hand (Karasik, 2002; Wodak, 2004; Novokhacheva, 2005).

The special niche among the types of the publicistic discourse is so-called "political discourse". T.M. Grushevskaya defines it as "communication between the author and the addressee on the basis of political informing aimed at attracting the addressee's attention, i.e. mass audience to the issues stated in the political newspaper discourse" (Grushevskaya, 2002). The purpose of the political discourse is not to describe, but to convince the addressee by awakening some or other intentions in the addressee, as well as to give the grounds for persuasion or induce to action (Bayley, 1985).

The linguistic ways of expressing opinions in political articles are diverse. As T.G. Dobrosklonskaya notes they range from direct explicit ones to hidden implicit ones and include a wide range of linguistic means, for example, various stylistic devices: comparisons, metaphors, anaphors, hints, etc. (Dobrosklonskaya, 2004). Such stylistic device as hint is of great research interest. 
N.A. Kachalova writes that, on the one hand, the use of this device in the text of a newspaper article expands the circle of potential readers; on the other hand, the hint enriches and beautifies the article, as well as makes the readers think and find the correct meaning of the utterance (Kachalova, 2013).

At present the researchers have not agreed on the definition of the term "hint" or the controversial issues concerning the relationship between the concepts "hint" and "allusion". In S.I. Ozhegov's dictionary, hint is interpreted as "a word or utterance, in which the idea that is not fully expressed can only be understood intuitively" (Ozhegov, 2007). According to A.N. Baranova, hint is to be distinguished from allusion due to the fact that intertextuality is an obligatory property of allusion (Baranov, 2007). According to P. Fontanier's definition allusion "makes it possible to detect the existence of a connection between the thing that is spoken about and the other thing that is not spoken about, but the idea of which arises from this connection" (Fontanier, 1977).

Following I.M. Kobozeva and N.I. Laufer in this article we do not make any fundamental difference between the allusion and the hint (Kobozeva \& Laufer, 1988).

The hint is a speech act, because it is an utterance with a specific goal - to hint the addressee at something, as well as it is realized with the help of various linguistic means. In this case it refers to an indirect speech act expressing the meaning of the content implicitly. It is the context of the utterance that plays an important role in the correct interpretation of the hint; it allows us to decode the meaning of the utterance, which depends on the goal pursued by the speaker (Kachalova, 2013). According to M. López Díaz, it is the allusion that assigns strongly marked heterogeneity to publicistic texts (López Díaz, 2006).

The hint is represented quite clearly in headline structures, which is determined by the specific role of the headline in the article text structure. As many scholars note the headline contains the main conceptual content of the material presented, which is concretized in the subhead and is subject to more detailed consideration in the text of the newspaper publication. In this case the headline complex and the text of the article are linked together by such text categories as prospection and retrospection. (Guslyakov, 2009).

Particular attention is drawn to the headings, which contain metaphorical constructions. Acute political struggle and desire to win the citizens' sympathy influence the politicians' use of conceptual metaphors, which differ in the initial sphere (source-sphere) of metaphorical transfer and target-sphere of metaphorical expansion (Kerimov, 2007).

\section{Results}

Relying on the classification of ways of expressing the hint through metaphors in Russian and German languages conducted by N.A. Kachalova in this article we analyze the headline structures built on the basis of metaphors selected from French newspaper political articles.

The study made it possible to identify the headlines of French newspaper articles, which contain "Anthropomorphic metaphor". In this case the concepts related to the initial conceptual spheres "Anatomy and physiology", "Disease", "Family" are analyzed. For example:

"Transition écologique: le Sénat donne un coup de pouce aux collectivités» - "Ecological transition: the Senate pushes local self-governing authorities" (Le Figaro, Novembre, 2017).

Using this headline the author of the article hints at the fact that the senators want to adopt an amendment, which concerns the collection of a tax on the protection of climatic conditions up to 10 euros per a resident, as a part of the consideration of the budget project for 2018. The tax provides for the signing of a contract between local self-government authorities and the State and the rest of the finances are to be spent on the reconstruction of public buildings and residential premises. 
The following example is related to the conceptual sphere "Disease":

Lorsque «les Etats-Unis éternuent, l'Amérique latine s'enrhume» - "When «the United States sneezes, Latin America gets a runny nose» (Monde diplomatique, Janvier, 2016).

This headline contains the hint at the fact that due to the turbulent political situation in the world the economic situation of Latin American countries has deteriorated sharply and the United States played a significant role in it.

In the language of modern French written media there are headlines related to the conceptual sphere "Family", for example: "De là à parler de favoritisme, il n'y a qu'un pas...» - "There is one step to nepotism...» (Monde diplomatique, Octobre, 2013).

The headline of this article hints at the privileged attitude, which unites the family of President of "Odebrecht", Marcelo Odebrecht, and former President of Brazil, Lula da Silva.

In the course of the research the headlines of political articles, which contain "Metaphor of nature", were identified. In this case the sources of metaphorical expansion are such conceptual spheres as "Animal world" and "Plant world", for example: Les loups solitaires de Boston - Boston Lone Wolves (Monde diplomatique, Juin, 2013). This headline refers to the article about the Boston Marathon bombing in the USA on April 15, 2013.

The following headline is no less interesting: "Une "épine dans les fesses» pour les Israéliens» - "Thorn in the flesh"of the Israelis" (Monde diplomatique, Octobre, 2014). In this case the point at issue is that the Coalition Government of Benjamin Netanyahu is again under the influence of the center-right nationalconservative political party "Likud".

The next type of headlines of political newspaper articles contains "Social metaphor" and explores the concepts related to such conceptual spheres as "Crime", "War", "Theater", "Game and sport".

For example, the following headline of the article refers to the conceptual sphere "Crime": «Au Brésil, «trois cents voleurs avec des titres de docteur» - "In Brazil "there are three hundred swindlers with doctoral degrees" (Monde diplomatique, Novembre, 2015).

In this example the hint is made that after the corruption scandal, which broke out in the largest Brazilian oil and gas company Petrobras in 2014, the country's economic situation deteriorated sharply and the deputies are more concerned with their personal enrichment than politics.

The following example can be referred to the concept «Theatre»: «Retour des chiites sur la scène yéménite» - "Return of the Shiites to the Yemeni Stage" (Monde diplomatique, Novembre, 2014). The article deals with the fact that Yemeni capital, Sana, was in the hands of Shiite Muslims and it weakened the influence of the Muslim Brotherhood's power.

On the pages of French newspapers the headlines of political articles related to the concept of "War" are used regularly, for example: "Une torpille contre l'habitat social» - "Torpedo against social housing" (Monde diplomatique, Novembre, 2016). Using this heading the author of the article unambiguously hints at the fact that Edward Philip's new reform to reduce the benefits for social housing leads not only to the reduction in housing payments, but also reduces the luxury tax that wealthy people pay. In protest against this reform on 14 October there were mass demonstrations throughout France.

The study revealed French headlines related to the conceptual sphere "Game and sport", for example:

"Le Hezbollah maître du jeu libanais» - "Hezbollah is the master of the Lebanese game" (Monde Diplomatique, Avril, 2016). 
This headline refers to the article stating that before his resignation Lebanese Prime Minister, Saad Hariri, reported a fear for his life accusing the Hezbollah movement and its Iranian allies of "enslaving" the country.

The study made it possible to identify the type of headlines that include "Artifact metaphor". The sources of metaphorical expansion are the conceptual spheres "House" and "Mechanism", for example: "Islamistes au pied du mur" - "Islamists have their backs to the wall" (Monde diplomatique, Mars, 2013).

This headline is a part of the conceptual sphere "Home". The hint at this headline leads the reader to the idea that in the moderate Islamic "Revival Party" in Tunisia there were disagreements and it weakened its position after the event that occurred on February 6, 2013 (the execution of the activist of the left by a group of unknown persons).

The conceptual sphere "Mechanism" includes the headline: "La Silicon Valley au révélateur de Donald Trump" - "Silicon Valley is underneath Donald Trump" (Télérama 30, Janvier, 2017).

In this article the headline suggests that after signing the decree of Donald Trump, which prohibits the entry of the citizens from 7 Islamic countries to the United States, the press expects violent protests from the "giants" of Silicon Valley, since many "start-ups" come from these countries and migrants traditionally represent the sources of various ideas.

In the course of the study one more type of metaphorical constructions included in the newspaper headlines - "Metaphors of irreality" - was identified. These constructions refer to otherworld, fantastic, non-existent characters and idols, events and phenomena (Klimova, n.d.).

For example: "Ce monstre anonyme, I'homme de la rue" - "This faceless monster is a man from the street" (Monde diplomatique, Avril, 2017). The headline of the article contains the hint at the fact that populism of the Republican Party embodied by Donald Trump is gaining momentum in the United States and the Democrats can only calm down with the illusion of their superiority.

"Etat islamique, un monstre providentiel" - "The Islamic State is a providential monster" (Monde diplomatique, Septembre, 2014).

This headline structure compares the terrorist organization "Islamic State" with a monster and points to its fast conquest of the territories of Iraq and Syria.

\section{Conclusion}

Thus, in order to interest the reader, draw attention to newspaper material, the most relevant events, the authors of French political articles use headlines containing the hint, i.e. acting as an indirect influence on the reader. Metaphors cope with this role effectively, because they are a reflection of political life; they help to create an idea of the nature of the state functioning, as well as influence the will, feelings and intellect of the reader through publicism.

The study showed that in the language of modern French press there is a great number of headline structures containing: "Anthropomorphic metaphor" with such conceptual spheres as "Anatomy and physiology", "Disease", "Family"; "Metaphor of nature" with such concepts as "Animal world", "Plant world"; "Social metaphor", the sources of this metaphorical expansion are such conceptual spheres as "Crime", "War", "Theater", "Game and sport"; "Artifact metaphor" with the concepts "House" and "Mechanism". Besides, in the course of the study it was revealed that one more type of headlines containing "Metaphor of irreality" is widely used in the language of the French written media. 


\section{References}

Baranov, A. N. (2007). Lingvistika namëka .Yazyk kak materiya smysla: sbornik statej k 90-letiyu N.YU. Shvedovoj. Moscow: Izdatel'skij centr «Azbukovnik», 443-461.

Bayley, P. (1985). Live oratory in the television age: The language of formal speeches. Campaign language: Language, image, myth in the U.S. presidential elections 1984. Bologna: Cooperativa Libraria Universitaria Editrice Bologna, 77-174.

Dobrosklonskaya, T. G. (2000). Teoriya i metody media lingvistiki: avtoref. dis. ... dokt. filol. nauk. Moscow.

Fontanier, P. (1977). Les Figures du discours. Paris, Flammarion: «Champs».

Grushevskaya, T. M. (2002). Politicheskij diskurs v aspekte gazetnogo teksta. St. Petersburg: RGPU im. A.I. Gercena.

Guslyakov, V. V. \& Guslyakova, N. V. (2009). Sootnoshenie gazetnogo zagolovochnogo kompleksa i teksta: ponyatie prospekcii i retrospekcii. Vestnik Stavropol'skogo gosudarstvennogo universiteta. Ser.Filologicheskie nauki, 62: 54-60. Rezhim dostupa: http://vestnik.stavsu.ru/62-2009/08.pdf

Kachalova, N. A. (2013). Pragmastilisticheskie sredstva vyrazheniya nameka v politicheskom diskurse: avtoref. dis. ... kand. filol. nauk. Saratov.

Karasik, V. I. (2000). Yazykovoj krug: lichnost', koncepty, diskurs. Volgograd: Peremena.

Kerimov, R. D. (2007). Tekstil'nye konceptual'nye metafory v politicheskom diskurse. Politicheskaya lingvistika. Yazyk v politicheskoj kommunikacii. Ekaterinburg, 23: 96-107.

Klimova, O. A. (n.d.). Politicheskaya metafora v vystupleniyah chlenov gosudarstvennoj Dumy XX-XXI vekov. Yazyk, kul'tura, professional'naya kommunikaciya $v$ sovremennom obshchestve. III mezhdunarodnaya nauchnaya Internet-konferenciya. Tambov. Rezhim dostupa: http://www.tsutmb.ru/nayk/int_konf/forum_vserossijskogo_studencheskogo_soyuza_v_tambo ve/konkurs_inicziativnyix_nauchnyix_proektov_2014_goda,_vyipolnya

Kobozeva, I. M. \& Laufer, N. I. (1988). Ob odnom sposobe kosvennogo informirovaniya. Izv. AN SSSR, Ser. literatury i yazyka, 5(47): 462-471.

López Díaz, M. (2006). L’hétérogénéité du discours publicitaire. Langage et Société, 2(116): 129-145.

Novohachyova, N. Yu. (2005). Stilisticheskij priyom literaturnoj allyuzii v gazetno-publicisticheskom diskurse konca XX - nachala XXI vekov: avtoref. dis. ... kand. filol. nauk. Stavropol'. Rezhim dostupa: $\quad$ http://www.dslib.net/russkij-jazyk/stilisticheskij-prijom-literaturnoj-alljuzii-v-gazetnopublicisticheskom-diskurse.html

Ozhegov, S. I. (2007). Slovar' russkogo yazyka. 24-e izdanie, ispravlennoe, Moscow: ONIKS.

Wodak, R. (eds.) (2004). Critical Discourse Analysis. Qualitative Research Practice. London: Sage.

\section{List of sources of factual material}

Monde diplomatique, Octobre, 2013

Monde diplomatique, Juin, 2013

Monde diplomatique, Septembre, 2014 
Monde diplomatique, Octobre, 2014

Monde diplomatique, Novembre, 2014

Monde diplomatique, Novembre, 2015

Monde diplomatique, Janvier, 2016

Monde Diplomatique, Avril, 2016

Monde diplomatique, Novembre, 2016

Monde diplomatique, Avril, 2017

Le Figaro, Novembre, 2017

Télérama 30, Janvier, 2017 